\title{
Daniel Defoe and Luis Buñuel's Robinson Crusoe: Individuality in film and fiction
}

\author{
Bassmah Bassam Khaled AlTaher \\ English Department, School of Languages, German Jordanian University, Madaba, Jordan \\ Email address: \\ bassmah.altaher@gmail.com
}

To cite this article:

Bassmah Bassam Khaled AlTaher. Daniel Defoe and Luis Buñuel's Robinson Crusoe: Individuality in Film and Fiction. International Journal of Literature and Arts. Vol. 2, No. 3, 2014, pp. 65-68. doi: 10.11648/j.ijla.20140203.12

\begin{abstract}
Individuality is an important aspect in human nature. Therefore, finding a path that could be called his own is the soul-searching journey Robinson Crusoe undertakes in his various voyages. In this paper, the theme of individuality is explored in the eighteenth century novel Robinson Crusoe by Daniel Defoe, and compared to its film adaptation by Luis Buñuel in 1954. Crusoe as a character and actor is analyzed and his actions set the scene of how man would do anything to escape routine and daily life habits. However, individuality has a price, and various consequences awaken Crusoe's remorse. Such consequences are dealt with skillfully in both novel and film. Nevertheless, this paper aims at portraying a wider picture of how an adapted character can behave the same way he has in the novel; free and liberated.
\end{abstract}

Keywords: Individualism, Film Studies, Theory of Adaptation, Robinson Crusoe

\section{Introduction}

Luis Buñuel (1900 - 1983), a famous film director is well known for his satire and images of surrealism found in many of his movies. At the age of fifteen, Buñuel questioned his faith in Christianity, and so turned to arts instead of science to find solitude. Soon, he became part of cinema and film making, and studied in Jean Epstein's film school, an avant-garde academy. Buñuel mostly made commercial comedies and melodramas, but he was also interested in reflecting political overtones and a sense of surrealism to many of his assignments. At the age of sixty, he began to satirize the bourgeoisie and the church as he explored social conventions and cultural stereotypes. Using simple, long takes, and clear-cut shots, he was able to produce a narrative that aids his character's revelations and actions. Such a technique can be seen in his 1954 film adaptation of Daniel Defoe's novel Robinson Crusoe (1719).

On the other hand, Daniel Defoe (1660-1731) was an English journalist, writer, and most importantly a trader. His novel Robinson Crusoe reflects the birth of the English novel during the Eighteenth century. This era witnessed a whole new world that was influenced by travelogues, exotic tales of the Mediterranean, and scientific breakthroughs. What mattered most in this era was the importance given to man's individuality and capitalism.
Such ideas were derived from a great critic named John Locke (163-1704).

Locke believes that every man has rights; born with a title, freedom, and individuality, for which a person is able to roam the lands freely. In nature, man finds his fullest enjoyment and satisfaction that is equal to all other men, and has the prerogative of property, land, family, and education. Moreover, Locke believes that a person must live within a society, because there he finds his strength and protection. Hence, individuals would be willing to join a united society in order to mutually protect their property and liberty. (Massimo, 166)

Moreover, the notion of Tabula Rasa, in which man is born as a clean slate is highly significant in Defoe's novel. Man acquires knowledge through experience and with external interactions with society. His identity is then shaped as the child grows older. Thus, knowledge is gained through experience. (Massimo, 166)

With Locke's philosophy dominating many writers and scholars throughout the eighteenth century, it is deductively said that Defoe had been inspired, and the becoming of Robinson Crusoe's solo journey as a cast away can refer to a man's need to experience life in its primitive forms to create knowledge. Defoe has been influenced by tales of sea, and Alexander Selkirk's true story of a cast away; a 
Scottish sailor who found himself in an abandon island for four years after a shipwreck. There are other stories that must have inspired Defoe in writing Robinson Crusoe, such as translated tales of Ibn Tufail by Hay ibn Yagdhan. Nevertheless, Defoe tries to make Robinson Crusoe as realistic as possible using his own styles and techniques, similar to the way Buñuel portrays Crusoe to be a passionate individual who thrives alone on an island.

To emphasize on the individuality of the protagonist in both the novel and film, the theory of adaptation and certain techniques used in film studies will be used. Moreover, Buñuel's cinematic styles adds to the importance of the character's individuality throughout the film.

\section{An in Depth Analysis}

Robinson Crusoe is written in the form of an episodic narration that contains explicit details of his daily life. Robinson Crusoe goes against his family wishes in pursuing a career in law, and sets sail for an adventure. Many a journey his ship has encountered misfortune. Once his ship encounters a storm, the second time he is captured by Sale pirates, and the third is the most fatal; he ventures to Brazil with the help of a Portuguese captain who ensured him of a plantation there. For wanting slaves and another taste of adventure, Crusoe sets sail only to find himself in a shipwreck and the sole survivor on a deserted island. This urge found in Crusoe implies how strongly he yearns for independence and individuality.

Luis Buñuel's film adaptation of the novel begins in the core of action when Crusoe is abandoned amd outcasted on a deserted island. The character of Crusoe was played by Dan O'Herlihy (1919 - 2005), who was nominated later on for Best Actor in the 1955 Academy Awards. Buñuel begins his movie with a scene, in which the novel Robinson Crusoe is shown to the audience, implementing that it is the original story taken from Defoe, a technique Linda Hutcheon calls the theory of adaptation.

According to Hutcheon, the theory of adaptation is an "attempt to think through some of the theoretical issues surrounding the ubiquitous phenomenon of adaptation as adaptation" (Hutcheon, xviii). Hutcheon believes that the original story is still valued, but this causes denigration when it comes to adaptation, "despite the longevity of adaptation as a mode of retelling" stories. (Hutcheon, xx) Moreover, fan culture and the audience are the ones who control the types of adaptations being used, whether in films, plays, or video games, a society's demands control the economy and imagination of how literature is portrayed theough various mediums. Yet, adaptations have their own time and space that creates a different atmosphere as seen in the novel, this is why Hutcheon calls this uniqueness a form of "repetition" and never a "replication," because adaptations repeat the story in many different ways, and the outcome of the new version is quite authentic in spite of its repetitive story. Hence, the popularity of film reaches a much wider audience than a novel in the twentieth and twenty first centuries.

In order to do justice to an adaptation, Hutcheon believes that there are three initial perspectives that ought to be taken into consideration. The first is the "formal entity or product...[that] is the transposition...[or] transcoding" of the original work through the usage of a medium, like a poem into film (Hutcheon, 7). The second is the creation process, in which adaptations involve "reinterpretation and then re-creation" of the story. This recreation allows the new version to maintain its originality and at the same time produce a different "aural and visual mode" (Hutcheon, 8). Finally, the third perspective involves the "process of reception" that associates the intertextual original work with its adapted work.

The first two perspectives Hutcheon provides will be applied on Buñuel's Robinson Crusoe's film adaptation of Defoe's novel in this paper, aided by certain techniques used in film studies to show how the original work is adapted and the creational process. Unquestionably, film studies are the core approach when dealing with films as a work of art, and not just for mere entertainment. T. S. Eliot explains the appreciation of different meanings thoroughly by stating: "We had the experience but missed the meaning / And approach to the meaning restores the experience...In a different form" (qtd in Buckland, 3). Hence film studies are valuable in analyzing significant forms of films.

There are two ways to approach film; internal perspective and external perspective. The focus will be on the internal perspective that is vividly seen in Buñuel's film, he used certain internal perspectives to explore Crusoe's individuality as a character on the silver screen. The internal perspective, as a matter of fact, "studies the film itself, in isolation from any historical, moral or social context. This approach is often referred to as poetic" (Buckland, 5) Therefore, the poetic or the internal approach will aid in analyzing Robinson Crusoe and study the way it is constructed; such as mise-en-scene, or the staging, and the editing and montage.

Before approaching the film, many critics have dealt with Daniel Defoe's novel quite individually, but did not particularly compare the novel to Luis Buñuel's 1954 film. The comparative study of Robinson Crusoe has been widely examined due to its multiple features in colonialism, slavery, religion, and imperialism. Michael Gavin approached the novel using realism and questioned whether Robinson Crusoe is a real or fictional character in a study entitled "Real Robinson Crusoe" (2013). He states:

What is the ontological status of fiction? Do fictional people exist? In Serious Reflections during the Life and Adventures of Robinson Crusoe (1720), Robinson Crusoe struggles with this very question. Defending his claim to exist in the face of accusations that his entire story was fanciful, Crusoe concedes that his life did not happen in any conventional sense; nonetheless, he asks readers to think of his life as real. During the seventeenth and eighteenth centuries, empirical philosophy recognized a 
perilous disconnect between knowledge and the actual existence of things in the world. Informed by recent work on the metaphysics of fictional entities, this article reads Crusoe's ontological self-defence in the context of John Locke's attempt, in An Essay Concerning Human Understanding (1690), to prove that knowledge was real despite being mediated entirely by our ideas. "Fiction" provides an inaccurate framework for understanding the books we call eighteenth-century novels because the concept entails ontological commitments at odds with the kind of knowledge these stories represent.

(Gavin, 301)

Apparently, to represent a true story in the eighteenth century had not only a more appealing manner towards it, but also for ontological commitments.

Gavin's argument on Defoe's novel is interesting, because in the film, Bunuel starts the movie with a whole scene capturing Defoe's novel on a table to create a sense of realism to the audience. Moreover, Buñuel uses realism with a pinch of surrealism to give Crusoe's chaotic thoughts clear images. First of all, a view of the novel's cover is clearly seen with the words Robinson Crusoe by Daniel Defoe. The camera focuses on the hard cover as it zooms in for a whole minute and a half. The actor Dan O'Herlihy talks in the background giving a brief description of Crusoe's life. This technique is called the long take, and it allows the audience to take in the plot of the story in the first two minutes. Next, Buñuel opens the mis-en-scene, the French word of staging. Originally mis-en-scene was taken from the theatre to show the set design, stage, lighting, and the arrangement of the movements of the characters. In film, the staging is quite different, art directors create important scenery that will be used in the film, like a real live jungle and a ship wreck for Robinson Crusoe. This allows reality seep into the silver screen, and set the stage for Crusoe to begin his adventures. Buñuel harmonizes between stage set and actors, so the set would not dominate the action or the actors.

By setting harmony in Crusoe's island, the action begins with Crusoe's survival and need to create shelter. Several scenes were taken in long takes in order to distance the spectator from the character and the events; a unique way in beginning a narrative structure. The exposition of the tale fills the background, as Crusoe goes to the ship wreck, build his fortress, and maintain a detailed diary of his daily routines. The diaries of course are read in the background by the actor, and thus performing action with a background narrator who fills in the gaps. As a result, an equilibrium is established when Crusoe is seen growing crops, taking care of his cat and dog, and expanding his claim of the island further.

As the film progresses, Buñuel uses the deep focus photography, which means that the foreground, middleground, and background of the island can be seen in one shot. This technique allows the director to film several actions happening at the same time, and decreases the need for editing. Moreover, the deep focus permits the unity of space and time in a scene, keeping it overflowing without any interruptions. By doing so, this allows emphasis on the actor's performance, and the development of the action that follows. Hence, Buñuel goes back and forth with long takes and deep focus, making the spectator comprehend the fatal situation Crusoe is witnessing on the deserted island.

Individuality of the actor or the character of Crusoe is what really dominates the film, and this is very similar to what Defoe was creating in his novel, for Crusoe is in the center, and the events revolve around him solely. As Locke states that man gains knowledge through experience, Buñuel makes sure that the island's set is perfect to give Crusoe his knowledge. Crusoe uses his senses and his emotions to acquire proper knowledge. Hence, Buñuel does not only show Crusoe as an individual character, but also implies his own individuality in the film, using as mentioned earlier, surrealism.

Surrealism appeared in many generic forms in the 1920s, by creating many visual images from the subconscious, art is created to show bizarre juxtapositions of various things. The surrealists were very much influenced by Sigmund Freud and his theories on the subconscious, they embraced idiosynrism and began to produce revolutionary thoughts that were directed to the subconsciousness of man's desires and fears.

In many of Buñuel's films, surreal imagery is his finger print, and it can be vividly seen in Crusoe's hallucinations when he was sick. Buñuel uses the continuity editing technique that breaks down Crusoe's hallucinations into many shots; "the way shots are edited together must therefore be controlled and regulated by a series of techniques that permit the spectator to fit them together like the pieces of a puzzle" (Buckland, 16). This gives the director control over the film, and a firm grip on the developing actions. In this scene, Crusoe sees his father, who is playing with water, and as he is sick and dying of thirst, his father chides his son for leaving them and going off on his own. Hence, several shots intervene, shots that do not make any sense, like Crusoe's father suddenly floating on water after we see him standing in Crusoe's cave, and then a pig siddenly appears by the father who is standing once again, and is persistently cleaning it. While cleaning the pig, the father is chiding his sick son, as if trying to cleanse his son's disobedience. He pours water all over the pig, wasting it on the filthy animal rather than his son who is begging him for water. Crusoe watches in awe and continues to plead his father for water to drink. Another shot interrupts the scene with Crusoe suddenly being tied up to a tree, and is in a flood, half drowned as it seems; Crusoe's hands and back are tied tightly as he tries to bend for a sip of water to quench his thirst. However, the water is far from his reach and he continues to beg his father for water. The hallucination ends with his father saying: "Your mother and I will forgive you, but God will not forgive you...[laughingly] you will die like a dog!" (Robinson Crusoe, 1954) His father's words echo like a 
curse, showing how Crusoe's will to go against his parents is unacceptable, and the audience understand why he is ill and expect him to feel remorse and repent. However, going against his parents is also an implication of Crusoe's strong will and desire for individualism, and to find his own way through life. This same theme of individuality is seen in Defoe's Crusoe, who also seeks for something more in life, and needs to find his own way. Crusoe gradually starts from the bottom as he tries to reach high positions and obtain wealth by fast means.

On the island, Crusoe is master to Friday, a position he welcomes heartily for the company and boost in his status. Crusoe is a prototype of a colonist who takes pride in his English heritage and imperialim (Said, 214). The way the English subject is presented in Defoe is one of pride and hierarchy. Buñuel makes his character a proud individual who believes in the goodness of his imperial country; a scene of Crusoe reminiscing his past is portrayed with various shots taken of his face. The back, the front and the sides are captured in just a few seconds while Crusoe drinks to his misfortunes and remembers his comrades. The scene is powerful in a sense that it allows the audience to feel his loss amd sympathize with him. Nevertheless, this internal solilique proves his becoming as a powerful master and individual upon the island. It is important to note that Buñuel's realistic world repeats the notion of God and His providence in many parts of the film. For example, when Friday learns of God through Crusoe, and he hears the tails of the devil, Friday questions God's power and purpose, bringing Crusoe to a halt and making him laugh the matter off. However, this scene shows how Buñuel himself is reflecting his own views of the Church. He had always mocked the Roman Catholic Church due to its hypocrisy. In an interview, Buñuel states that: "I didn't deliberately set out to be blasphemous, but then Pope John XXIII is a better judge of such things than I am" (Wood, 2013). The issue of religion is a major part of Crusoe's individuality, not only is his English blood superior to Friday and Xury, but also his beliefs.

\section{Conclusion}

All in all, the adaptation of Robinson Crusoe sparks the adventure of an individual who defies parents and God on a soul searching journey to find himself. Both novel and film did Crusoe justice in developing the plot, as they emphasize the importance of the actor and his journey to be a priority above any other action. Hence, Buñuel succeeded in visualizing Crusoe's world through surrealism, bringing his own individuality to the silver screen to announce to the world his chaotic thoughts and fears of the subconscious. Whether many directors adapted the idea of Defoe's castaway, Buñuel's film stands out in its montage and intricate plot.

\section{References}

[1] Axmaker, Sean. "Luis Buñuel." Fandor.com. web Dec 18, $2013<$ http://www.fandor.com/filmmakers/director-luisBuñuel -120>

[2] Buñuel, Luis. My Last Sigh: The Autobiography of Luis Buñuel. New York: Vintage, 2013.

[3] Buckland, Warren. Film Studies. 2nd Ed. London: Hodder Education, 2003.

[4] Defoe, Daniel. Robinson Crusoe. Beirut: York Press, 2010.

[5] Gavin, Michael. "Real Robinson Crusoe." Eighteenth Century Fiction, Vol. 25, no.2. McMaster University, 2013.

[6] Hutcheon, Linda. A Theory of Adaptation. 2nd Ed. New York: Routledge, 2013.

[7] Robinson Crusoe. Dir. Luis Buñuel. United Artists, 1954. Film

[8] Said, Edward. Culture and Imperialism. New York: Knopf Doubleday Publishing Group, 2012.

[9] Salvador, Massimo. Locke and Liberty. London: Pall Mall Press, 1956.

[10] Wood, Micheal. "Viridiana: The Human Comedy." Criterion Collection. Retrieved January 10, 2014. 